\title{
CONGRESSIONAL CONTROL OF THE ELECTORAL SYSTEM
}

\author{
C. C. TANSII
}

The overwhelming victory of $\mathrm{Mr}$. Coolidge in the November election obviated certain embarrassing situations that might have arisen if the vote had been more evenly divided between the three leading contestants. If, as had been freely predicted, Mr. Davis and Mr. LaFollette had been able to carry a considerable number of the Western states, Mr. Coolidge might not have secured the required majority in the Electoral College and the election would have been thrown into the House of Representatives for final decision. In the event of a close election the determination and allocation of the electoral votes of the different states would have been of grave importance, and the responsibility would have rested entirely upon Congress. How Congress acquired this power of decision is the purport of this study.

In the early days of our government the opinion widely prevailed that the determination of the electoral votes of the states was vested either in the state governments or in the President of the Senate. Continuity of purpose through successive sessions has not been a marked attribute of Congress. But the question of the determination of the electoral count has been a conspicuous exception, and the possibilities of control of the electoral system have led Congress, despite changes in membership and the usual party differences, to pursue a consistent policy. Step by step Congress has assumed the control of the electoral count. First, tellers were appointed to assist the President of the Senate in the computation; next the President of the Senate was induced to forego the practice of breaking the seals; and finally, Congress determined and allocated the count. At present, Congressional control is so firmly established that only a few students of the subject are interested in, or comprehend, the process of its evolution.

\section{ESTABLISHMENT OF THE ELECTORAL COLLEGE}

The concept of an electoral college for the election of a national executive was the product of that storm and stress period of American history that began in the closing days of the Revolution and continued until the organization of the federal government in 1789 . The revolutionary fervor, so pronounced in I775, rapidly cooled, and by I78I a definite conservative reaction became manifest. ${ }^{1}$ Under the Articles of

${ }^{1}$ Ford, The Rise and, Growth of American Politics (1898) chs. 1, 3, 4, 5; Beard, An Economic Interpretation of the Constitution (19I3) ch. 5; Merriam, Anerican Political Theories (1903) chs. 2, 3. 
Confederation four important groups of personalty interests had been adversely affected-money, public securities, manufactures, and trade and shipping. These economic classes, therefore, quickly took the lead in advocating a Constitutional Convention to revise the Articles of Confederation along certain positive lines. ${ }^{2}$

The membership of this Convention which finally met in Philadelphia on May 25, 1787 , was distinctly conservative. Most of the members came from towns on or near the coast, that is, from the regions in which personalty was largely concentrated, and not one member in his immediate personal economic interests represented the small farming or mechanic classes. ${ }^{3}$ The way that things had been moving since the colonies had become independent states "had greatly excited among the delegates the traditional prejudice against democracy." "

Roger Sherman solemnly declared that he believed "the people immediately should have as little to do as may be about the Government"; while Elbridge Gerry was convinced that the evils of the times flowed "from the excess of democracy." "The people do not want virtue, but are the dupes of pretended patriots." ${ }^{\prime}$ With reference to the popular election of a President, George Mason thought such a procedure to be "as unnatural . . . as it would be to refer a trial of colours to a blind man." Thus, it is evident from a study of the political doctrines of the framers that they "had a considerable distrust of the people"; ${ }^{7}$ and that the electoral college was the result of that distrust.

In the so-called Virginia Plan, in the Pinckney Plan, and in the New Jersey Plan, the national executive was to be elected by the national legislature. In the discussions that arose the question of the popular election of the chief executive was brought forward by James Wilson of Pennsylvania who warmly urged the adoption of such a provision. The Convention, however, on July I7 adopted a proposal to the effect that the national executive be chosen by electors to be appointed by the national legislature. ${ }^{8}$ Two days Tater, on July I9, this proposal was amended so as to provide for the election of the presidential electors by the state legislatures. ${ }^{9}$ On July 26 the Convention reversed its decision of July 19, and agreed that "a National Executive be instituted ... to consist of a single person ... to be chosen by the National legislature ... for the term of seven years." ${ }^{10}$ The task of drafting a constitu-

${ }^{2}$ Beard, An Economic Interpretation of the Constitution (I9I3) 149, et seq.

${ }^{3}$ Beard, op. cit. ch. 5; Ford, Rise and Growth of American Politics (1898) chs. 4, 5; Goodnow, Principles of Constitutional Government (1916) 126-128;

Schlesinger, New Viczpoints in American History (Ig22) chs. 3, 4, 5.

'Ford, op. cit. 45.

${ }^{5}$ Hunt and Scott, Debates in the Federal Convention of $I 787$ as Reported by James Madison (I920) 31-33.

"Hunt and Scott, op. cit. 269.

'Goodnow, Principles of Constitutional Govermment (I916) I27.

${ }^{8}$ Hunt and Scott, op. cit. 270, 27 I.

IIbid. 287.

${ }^{10}$ Ibid. 326. 
tion from the resolution adopted by the Convention was then referred to the Committee of Detail, and the Convention adjourned until August 6.11

On August 6, the Convention resumed its sessions and the Committee of Detail reported its draft of a constitution. Section I of Article X dealt with the election of the Executive, and read in part as follows: "The Executive Power of the United States shall be vested in a single person. ... He shall be elected by ballot by the Legislature. $\mathrm{He}$ shall hold his office during the term of seven years; but shall not be elected a second time."12 On August 24 when the subject of the election of the Executive was again discussed by the Convention, Mr. Carroll moved that the Executive be elected "by the people," and not by the national legislature. ${ }^{13}$ This motion was promptly and overwhelmingly negatived, only Pennsylvania and Maryland being in favor of it.

On this same day Gouverneur Morris inveighed strongly against the election of the Executive by the national legislature, and moved instead that the President "be Chosen by Electors to be chosen by the People of the several States."14 This motion, however, suffered the same fate as that proposed by Mr. Carroll. ${ }^{15}$

On August 3I the Convention referred "such parts of the Constitution as have been postponed, and such parts of Reports as have not been acted upon," to a Committee of Eleven. ${ }^{16}$ On September 4 this committee reported an entirely new provision dealing with the election of the Executive. Instead of the clause agreed upon in the Convention providing for the election of the Executive by the national legislature and serving for a term of seven years, the report of the Committee of Eleven read as follows: "He shall hold his office during the term of four years, and together with the Vice-President, chosen for the same term, be elected in the following manner, viz. Each State shall appoint in such manner as its Legislature may direct, a number of electors equal to the whole number of Senators and members of the House of Representatives to which the State may be entitled in the Legislature. The Electors shall meet in their respective States, and vote by ballot for two persons, of whom one at least shall not be an inhabitant of the same State with themselves; and they shall make a list of all the persons voted for, and of the number of votes of each, which list they shall sign and certify and transmit sealed to the Seat of the Government, directed to the President of the Senate... The President of the Senate shall in that House open all the certificates; and the votes shall be then and there counted. The Person having the greatest number of votes shall be the President, if such number be a majority of that of the electors; and if there be more than one who have such majority, and have an equal number of votes, then the Senate shall immediately choose by ballot one of them for President; but if no person have a majority, then from the five

\begin{tabular}{lll}
\hline${ }^{11}$ Ibid. $332-337$. & ${ }^{13}$ Ibid. $46 \mathrm{I}$. & ${ }^{15}$ Ibid. 463. \\
${ }^{22}$ Ibid. 243. & ${ }^{14}$ Ibid. 463. & ${ }^{16}$ Ibid. 502.
\end{tabular}


highest on the list, the Senate shall choose by ballot the President. And in every case after the choice of the President, the person having the greatest number of votes shall be Vice-President: but if there should remain two or more who have equal votes, the Senate shall choose from them the Vice-President. The Legislature may determine the time of choosing and assembling the Electors, and the manner of certifying and transmitting their votes." 17

This provision for the election of the Executive by an Electoral College was modelled upon that section of the Maryland Constitution of I776 which outlined such a procedure for the election of state senators. ${ }^{18}$ It was this provision, as modified by subsequent amendments adopted by the Convention, that was finally incorporated in the finished draft of the Constitution and became, after ratification by the states, a part of the supreme law of the land.

II

CONGRESSIONAL LEGISLATION AND REgULATIONS PRESCRIBING RULES OF PROCEDURE FOR THE ELECTORAL COLLEGE

The first act of Congress regulating the procedure of the Electoral College was that of March I, I792. This act provided that "electors shall be appointed in each state for the election of a President and Vice President of the United States, within thirty-four days preceding the first Wednesday in December, one thousand seven hundred and ninetytwo, and within thirty-four days preceding the first Wednesday in December in every fourth year succeeding the last election, which electors shall be equal to the number of Senators and Representatives, to which the several states may by law be entitled at the time, when the President and Vice-President, thus to be chosen, should come into office." It was further enacted "that the electors shall meet and give their votes on the said first Wednesday in December, at such place in each state as shall be directed, by the legislature thereof; and the electors in each state shall make and sign three certificates of all the votes by them given, and shall seal up the same certifying on each that a list of the votes of such state for President and Vice-President is contained therein, and shall by writing under their hands, or under the hands of a majority of them, appoint a person to take charge of and deliver to the President of the Senate, at the seat of government, before the first Wednesday in January then next ensuing, one of the said certificates, and the said electors shall forthwith forward by the post-office to the President of the Senate, at the seat of government, one other of the said

\footnotetext{
${ }^{17}$ Ibid. 507 .

${ }^{13}$ Fisher, The Evolution of the Constitution, (I9I0); (1890) I Annals of AM. Acad. 229; Ames, Proposed Amendments to the Constitution (I896) 76, 153-155.
} 
certificates, and shall forthwith cause the other of the said certificates to be delivered to the judge of that district in which the said electors shall assemble."

It was also enacted that the "executive authority of each state shall cause three lists of the names of the electors of such state to be made and certified and to be delivered to the electors on or before the said first Wednesday in December, and the said electors shall annex one of the said lists to each of the lists of their votes." And "if a list of votes, from any state, shall not have been received at the seat of government on the said first Wednesday in January, that then the Secretary of State shall send a special messenger to the district judge in whose custody such list shall have been lodged, who shall forthwith transmit the same to the seat of government." Further, "that Congress shall be in session on the second Wednesday in February, one thousand seven hundred and ninety-three, and on the second Wednesday in February succeeding every meeting of the electors, and the said certificates, or so many of them as shall have been received, shall then be opened, and the votes counted, and the persons who shall fill the offices of President and VicePresident ascertained and deciared, agreeably to the constitution."1s

In the following year, I793, provision was made for the counting of the electoral vote. On February 5, I793 the House of Representatives adopted a resolution to the effect that "a committee be appointed, to -join such committee as may be appointed by the Senate, to ascertain and report the mode of examining the votes for President and VicePresident, and of notifying the persons who shall be elected of their election."20 The Senate was immediately advised of this action taken by the House, and on February Ir, 1793, Mr. King, from the joint committee appointed on February 6, reported, "that the two Houses shall assemble in the Senate Chamber on Wednesday next, at twelve o'clock; that one person be appointed a teller, on the part of the Senate, to make a list of the votes as they shall be declared; that the result shall be delivered to the President of the Senate, who shall announce the state of the vote, and the persons elected, to the two Houses assembled."21 On the same day Mr. William Smith, "from the committee appointed on the part of the House, jointly, with a committee appointed on the part of the Senate to ascertain and report a mode of examining the votes for President and Vice-President of the United States," reported a similar resolution with the addition that "two persons be appointed tellers on the part of this House."22

On February 13, the Secretary of the Senate notified the House of Representatives that the Senate was ready to meet them in the Senate Chamber for the purpose of counting the electoral vote. The "two

${ }^{19}$ Act of Mar. I, I792 (I Stat. at I. 239).

${ }^{20} 3$ ANnals of Congress, $86 \mathrm{r}$.

2 Supra note 20 , at p. 644 .

${ }^{2}$ Supra note 20 , at p. 873 . 
Houses having accordingly assembled, the certificates of the Electors of the fifteen States in the Union, which came by express, were, by the Vice-President, opened, read, and delivered to the tellers appointed for the purpose, who, having examined and ascertained the votes, presented a list of them to the Vice-President; which list was read to the two Houses." 23

This action on the part of the two houses in appointing tellers was fraught with the most important consequences. 'In the opinion of many publicists the plain purpose of the framers of the constitution was to have the function of counting the electoral votes devolve solely upon the President of the Senate. Congress, of course, could pass a general law providing for the authentication of state acts and records so that there could be no doubt in the mind of the President of the Senate as to which papers were certificates, and which were not. ${ }^{24}$ According to the late Professor Alexander Johnston, it was "the intention of the system of American constitutional government that the President of the Senate should canvass the votes: in accordance with a general authenticating law, if Congress would or could pass such a law; otherwise according to his own best judgment. The members of the convention were not such bungling workmen as the modern idea of the 'electoral count' would make them. They were not so foolish as to entrust the canvass to two independent agents, equal in rank, and without an arbiter in case of disagreement. . . Had Congress done its plain duty in the premises; and carried out the system in its letter and spirit, as the convention of I787 did, it is evident that that honorable body would have been reduced to its proper constitutional position as the official witness and register of the votes which have been declared by the President of the Senate in accordance with general law... The constitution, by concentrating responsibility, found the safest place for the canvass of the votes, and it left the 'count' unassigned and unguarded because there was no need of any other guard than the laws of arithmetic." The first principal inroad upon this prerogative of the President of the Senate "came from the innocent and proper appointment of 'tellers' by the two houses 'to examine the votes." "

In I797, in the counting of the electoral vote, the course of procedure adopted in I793 was substantially followed. As it happened, the Legislature of Vermont had appointed electors without first enacting a law prescribing the manner of their appointment. ${ }^{25}$ The Vermont certificate representing the four votes of that state was accepted without question by the Vice-President, John Adams, who thus insured his own election to the presidency. ${ }^{26}$

For the first two elections the electoral system worked smoothly, but

${ }^{23}$ Supra note 20 , at p. 645 .

"I Lalor, 2 Cyc. Pol. Sc. \& Ec. Hist. of U. S. (I904) 62, 63.

${ }^{28}$.Dougherty, The Electoral System of the United States (I906) 33, 34.

${ }^{20}$ Stanwood, History of the Prèsidency (IgI2) $52,53$. 
during the election of I796 its defects were quickly made manifest, the President and Vice-President representing different political parties. It was clearly seen that the existing system might also lead to confusion as to the choice within one party of the President and Vice-President. To obviate such a contingency, Mr. Smith, of South Carolina, on January 6, I797, proposed the following resolution: "That the third clause of the first section of the second article of the Constitution of the United States ought to be amended in such manner as that the Electors of a President and Vice-President be directed to designate whom they vote for as President and for Vice-President."27 On January 24, I798, ${ }^{28}$ on February $16,1799,{ }^{29}$ and on February 4, I800, similar amendments were proposed in Congress. ${ }^{30}$

On Februatry I4, I800, Senator James Ross, of Pennsylvania, reported a bill to regulate the electoral count. It made provision for the organization of a grand committee composed of six senators and six representatives, and the Chief Justice of the Supreme Court, with authority to examine and make the final decision, in secret session, of all disputes and objections relative to the electoral count. ${ }^{31}$ This bill therefore, represents the first serious attempt on the part of Congress to control the electoral count, and is extremely important as a precedent for subsequent legislation. The bill was open to serious constitutional objections, and on March 28, I80o, Charles C. Pinckney, of South Carolina, the candidate of the Federalist Party for the Presidency, delivered in the Senate a closely reasoned attack upon the whole theory of Congressional regulation of the electoral count. Pinckney had been a member of the Constitutional Convention, and later took a leading part in securing the ratification of the Constitution in South Carolina. ${ }^{32}$ As one of the framers of the Constitution he felt that he had a special knowledge of the true purport of its provisions. This view he stressed as follows: "Knowing that it was the intention of the Constitution to make the President completely independent of the Federal Legislature, I well remember it was the object, as it is at present, not only to give to Congress no interference in, or control over, the election of a President. It is made their duty to count over the votes in a convention of both Houses, and for the President of the Senate to declare who has the majority of the votes of the Electors so transmitted. It never was intended, nor could it have been safe, in the Constitution, to have given to Congress thus assembled in convention, the right to object to any vote, or even to question whether they were constitutionally or properly

${ }^{27} 6$ ANNALS OF CONGRESS, I824.

${ }^{2} 7$ ibid. 493.

28 ibid. 2919.

${ }^{20}$ ro ibid. 5 Io.

"Io ibid. I29. This bill was not printed in the Annals, but a copy taken from the Philadelphia Aurora of Feb. I9, I800, appears in House Misc. Doc. No. I3, 44th Cong., 2d sess. pp. I6ff.

"Beard, The Economic Origins of Jeffersonian Democracy (Igr5) 57, 59. 
given. This right of determining the manner in which the Electors shall vote; the inquiry into the qualifications, and the guards necessary to prevent disqualified or improper men voting, and to insure the votes being legally given, rests, and is exclusively vested in the State Legislatures. ... To give to Congress, even when assembled in convention, a right to reject or admit the votes of States, would have been so gross and dangerous an absurdity, as the framers of the Constitution never could have been guilty of." 33

The bill was passed in the Senate by a vote of 16 to $12,^{34}$ and was then sent to the House where it was amended and returned to the Senate. The two Houses could not agree upon amendments, so the bill was finally lost. The importance of this proposed legislation lies in the fact that this Senate bill was in many respects the same as the later twenty-second joint rule, and served as a precedent for the subsequent action taken by Congress.

The election of 1800 with the resulting tie in the electoral vote for Jefferson and Burr at last awakened the country to the necessity for a constitutional amendment. In December, I803, Congress adopted a resolution proposing an amendment to the Constitution whereby presidential electors were required to designate which votes they cast for President, and which for Vice-President. Ten states promptly ratified the proposed amendment, and on September 25, 1804, the Secretary of State proclaimed the amendment to be in force. ${ }^{35}$

This amendment, which happened to be the twelfth, was really a constitutional recognition of the existence of political parties. $U_{p}$ to this time it was presumed that the electoral colleges were deliberative bodies but "after the third presidential election there began to be congressional oversight of the matter. From I800 to I824 there was an unbroken succession of caucuses of the Republican members of Congress to direct the action of the party electors." ${ }^{36}$

Before I800 no one had any positive knowledge of how an elector voted until the certificate was opened; after that year the votes of electors were generally known several months before they were formally opened and counted by the President of the Senate. That officer continued to follow precedents, but often did so in a careless and perfunctory manner. In I805 Mr. Burr "merely broke the seals of the certificates and handed them to the tellers to be read aloud to them." 37 In the election of 1808 several towns from Massachusetts petitioned Congress that "the late appointment of Electors of President and Vice-

\footnotetext{
${ }^{3}$ Io Annals of Congkess '130; Dougherty, op. cit. supra note 25, pp. 58-68; McKnight, The Electoral System of the United States (1878) 262-269.

${ }^{34}$ io Annals of Congress I46; O'Neil, The American Electoral System, (1887) 77-83; Lalor, op. cit. supra note 24, p. 66.

${ }^{25}$ Ames, Proposed Amendments to the Constitution (1896) 78, 79.

so Wilson, Congressional Government (I885) 246, 247.

Lalor, op. cit. supra note 24, p. 64; McKnight, op. cit. supra note 33, pp. 293, 295 .
} 
President of the United States, by the Legislature of that State, is irregular and unconstitutional," and they prayed "that the Congress of the United States, when the Electoral votes are opened and counted, will take the subject into their consideration, and prevent the establishment of so dangerous a precedent."38.

On February 6, 1809 the House of Representatives adopted the following resolution: "Resolved, That the Clerk of this House do carry to the Senate the several memorials from sundry citizens of the State of Massachusetts, remonstrating against the mode in which the appointment of Electors for President and Vice-President has been proceeded to on the part of the Senate and House of Representatives of said State, as irregular and unconstitutional, and praying for the interference of the Senate and House of Representatives of the United States, for the purpose of preventing the establishment of so dangerous a precedent."39

The Senate neglected to take any action upon this resolution, and when the electoral votes were formally opened and counted on February 8,1809 no interference by the joint houses was attempted. ${ }^{40}$ On this same day Mr. Hillhouse "observed that the returns from one of the States appeared to be defective, the Governor's certificate not being attached to it. He thought that this might be as proper a time to notice it as any." But "nothing farther" was "said on the subject," and the President of the Senate announced the result of the electoral count. ${ }^{41}$

In I8I7 the first objection to an electoral vote was offered. $U_{p}$ to this time the message sent from one House to the other relative to the electoral count had been a notice of readiness "to attend at the Opening and Counting"; in $18 \mathrm{I} 7$ it was changed to a notice of readiness "to open and count the votes for President and Vice-President of the United. States." 42 The change is significant. On February I2, I817 while the electoral count was in progress, Mr. Taylor, of New York, arose and objected to the electoral vote of Indiana because of "the electors . . . having been elected in Indiana before she was declared to be admitted into the Union by Congress." 43

The Speaker of the House interrupted Mr. Taylor and "said that the two Houses had met for the purpose-the single specific purposeof performing the Constitutional duty which they were then discharging, and that while so acting, in joint meeting, they could consider no proposition nor perform any business not prescribed by the Constitution." 44 But this rebuff did not deter Mr. Taylor, who returned to the attack. Resolutions to the effect that Indiana's vote "ought" to be accepted, or that "Indiana had a right to vote in December last," were

${ }^{33}$ I9 ANNALS OF CoNGRess 9I0, I04I.

$\approx$ Ibid. I376, I377.

${ }^{10} \mathrm{Ibid}$. I425, 1426.

"Ibid. 1423, 1424.

The Presidential Counts (1877) 29-34.

Ibid. 29-34.

"Ibid. 29-34 
offered in both Houses, but no action was taken upon them, and the votes of Indiana were counted without any further interference.

Although Congress had declined to take any definite action with reference to the electoral vote of Indiana, yet since $x 793$ there had been going on a progressive change in that direction. These changes may be clearly perceived in the different phraseology used in the messages from the two Houses announcing their readiness to attend the electoral count. They are as follows: "(I793-1805) that they are ready to meet one another 'to attend at the opening and counting of the votes'; (I809I8r3), 'to attend $i n$ the opening and counting of the votes'; ( $18 \mathrm{r} 7)$ 'to proceed in opening the certificates and counting the votes,' or 'to proceed to open and count the votes. " 45

In I82I Missouri's votes were disputed, and for the first time in our history the power of Congress to control and canvass the electoral votes was maintained. ${ }^{46}$ In this instance Congress not only claimed the right to canvass the electoral votes, but also refused to fulfill the constitutional charge that "the votes shall then be counted." The difficulty arose out of the wording of the fourth clause of the twenty-sixth section of the third article of the Missouri Constitution of I820, which read:

"It shall be their [i.e. state legislature] duty, as soon as may be necessary,

"First, to prevent free negroes and mulattoes from coming to, and settling in, this State, under any pretext whatsoever." ${ }^{37}$

A majority in the national Congress was determined not to permit the admission of Missouri into the Union as a state until the above clause .was expunged or made inoperative. As it was questionable whether the legislature of Missouri would accept this condition, protests were at once made in Congress relative to the counting of the electoral votes of Missouri.

On February 4, I82I, Henry Clay introduced a resolution providing for an alternative count: "Were the votes of Missouri to be counted, the result would be, for A. B. for President of the United States, votes; if not counted, for A. B. as President of the United States, votes; but in either event A.B. is elected President of the United States." 48

Vigorous objection to this resolution was at once voiced by John Randolph. "He could not recognize in this House or the other House, singly or conjointly, the power to decide on the votes of any State. . . He maintained that the Electoral College was as independent of Congress, as Congress of them; and we have no right to judge of their proceedings. Mr. R. said he would rather see an interregnum, or see

\footnotetext{
¿soore, Federal and State Constitutions (1877) I107.

${ }^{\text {t6 }}$ Shoemaker, Missouri's Struggle for Statehood (I916) ch. Io.

"37 ANNAIS OF CONGRESS II 48.

"Ibid. II47.
} 
no votes counted at all, than see a principle adopted which went to the very foundation on which the Presidential office rested." 49

Mr. Floyd, of Virginia, strongly supported Mr. Randolph. "We have been going on for several years," he observed, "accumulating power until scarcely any is left but in Congress. If they had any power over the votes in Missouri at all, it was when her votes were first received; but no such power existed. The votes of Indiana, at the last election for President, were counted when precisely in the same situation as those of Missouri now. He protested against this assumption of authority on the part of Congress, and wished to show his disapprobation of the resolution in the strongest manner." 50

In his answer to the protests of Mr. Randolph and Mr. Floyd, Henry Clay developed a new doctrine with reference to the control of the electoral count. In his opinion "there was no mode pointed out in the Constitution of settling litigated questions arising in the discharge of this duty; it was a casus omissus; and he thought it would be proper, either by some act of derivative legislation, or by an amendment to the Constitution itself, to supply the defect."51

This view that there was a casus omissus in the Constitution with regard to the electoral count was the accepted view in Congress for the next forty years. Clay now pressed his resolution providing for an alternative count, and Congress adopted the following device: "Were the votes of Missouri to be counted, the result would be: For James Monroe, of Virginia, for President of the United States, 23I votes; if not counted, for James Monroe, of Virginia, 228 votes."52

In 1837 the question of the control of the electoral count again arose, this time with reference to the electoral votes of Michigan. As on the previous occasion the device of the alternative count was resorted to, and no decision was made as to the controlling authority in case of electoral disputes. In this regard the following excerpt from the report of the Senate committee is pertinent and interesting: "Should a case occur in which it became necessary to ascertain and determine upon the qualifications of electors of President and Vice-President of the United States, the important question would be presented, What tribunal would, under the Constitution, be competent to decide? Whether the respective colleges of electors in the different States should decide upon the qualifications of their own members, or Congress should exercise the power, is a question which the committee are of opinion ought to be settled by a permanent provision upon the subject."5s

It was during the discussions relative to the counting of the electoral votes of Michigan that Mr. Lyon propounded to Mr. Grundy the fol-

\footnotetext{
Ibid. II 48 .

${ }^{\infty}$ Ibid. II49.

"I Ibid. II52.

"Ibid. 1164 .

ws (I836) Cong. GioBe I5I-153, I66-I67; Stanwood, History of Presidential Elections (r888) IIg-I2r.
} 
lowing searching inquiry. "What course would the committee have taken in case the vote of Michigan had varied the result? Would Michigan in such case be deprived of her vote?"

Mr. Grundy's answer was frankness itself: "The gentleman should not expect him to answer a question which the wisest of their predecessors had purposely left undetermined. What might be done under the circumstances adverted to by the Senator from Michigan, should they ever occur, the wisdom of the day must decide." 54

At every election subsequent to I82I the tellers of both houses of Congress assumed more and more of the functions of the President of the Senate with referrence to the electoral count. In I829 that official surrendered to them the declaration of the result of the count. ${ }^{.5}$ In $\mathrm{I} 845$ he no longer took the trouble to exercise his former function of breaking the seals of the certificates. ${ }^{56}$ In 1857 , the President of the Senate made the following interesting observation: "The presiding officer considers that the duty of counting the vote has devolved on the tellers under the concurrent order of the two Houses; and he considers, further, that the tellers should determine for themselves in what way the votes are verified to them, and read as much as they may think proper to the two Houses assembled."

In 1865 the climax of Congressional control was reached, and the occasion for this assertion of jurisdiction was the breach between the Executive and Congress relative to the reconstruction of the southern states. ${ }^{58}$ On January 30 , I865 the House passed a resolution that is now generally known as the "22d Joint Rule." On February 6, after amendment, the House resolution passed the Senate, and Congressional control over the electoral count was firmly established. ${ }^{50}$

On February 8, I865 the two Houses jointly assembled to witness the electoral count. At the appointed time the Vice-President delivered the following unusual statement: "The Senate and House of Representa-

(1836) Cong. GLobe I52.

${ }^{65}$ Lalor, op. cit. supra note 24, p. 64.

${ }^{50}$ McKnight, op. cit. sulpra note 33, 305-306.

On January 23, I845, Congress passed a law amending the act of Mar. I, I792. Under the act electors were required to be appointed in each State within thirtyfour days preceding the first Wednesday in December, 1792, and within thirtyfour days preceding the first Wednesday in December in every fourth year thereafter. Under the terms of the act of Jan. 23, I845, Congress prescribed that the electors should be appointed in each state on the Tuesday next after the first Monday in the month of November of the year in which they were to be appointed. Each State was further authorized to pass appropriate legislation for filling any vacancies that might occur in its college of electors, and in case of failure to make a choice of electors at an election duly held. it was provided that electors might be appointed on a subsequent day in such manner as the State might by law prescribe. Act of Jan. 23, 1845 (5 Stat. at L. 1845).

${ }^{67}$ The Presidential Counts (I877) I00-103; Burgess, Reconstruction and the Constitution (1902) 20-25.

${ }^{s}$ McCarthy, Lincoln's Plan of Reconstruction (Igor).

${ }^{\infty}$ House Misc. Doc. No. 13, 44th Cong. 2d Sess., 147-229. 
tives having met under the provisions of the Constitution for the purpose of opening, determining, and declaring the votes for the offices of President and Vice-President of the United States for the term of four years commencing on the fourth of March next, and it being my duty, in the presence of both Houses thus convened, to open the votes, I now proceed to discharge that duty." ${ }^{\circ 0}$ The electoral count proceeded under the terms of the 22d Joint Rule which provided in part as follows: "If, upon the reading of such certificate by the tellers, any question shall arise in regard to counting the electoral votes therein certified, the same having been stated by the presiding officer, the Senate shall thereupon withdraw, and said question shall be submitted to that body for its decision; and the Speaker of the House of Representatives shall in like manner submit said question to the House of Representatives for its decision; and no question shall be decided affirmatively, and no vote objected to shall be counted, except by the concurrent votes of the two Houses."61

On February 4, Congress had passed a joint resolution excluding the electoral vote of the Southern States, and under the provisions of this law, the Houses in joint session rejected the returns of Louisiana and Tennessee. This was the first instance of the rejection of the votes of a State by Congress, and it was not done by a Congressional canvass of the electoral votes of the States, but by the President of the Senate, agreeably to this new "law of the land." 62

The adoption of the 22d Joint Rule marked the beginning of a new era with reference to the electoral count. Since the organization of the national government in 1789 there had obtained three different theories as to the opening of the-electoral certificates and the counting of the electoral votes. According to McKnight, in his Electoral System of the United States, "the first theory is, that the President of the Senate shall count the votes; the second is that there is a casus omissus in this regard; and the third is that the two Houses present shall count."'ss From the time of the first Congress in 1789 until $\mathrm{I} 82 \mathrm{I}$ it was the unquestioned custom for the President of the Senate to "declare" the votes officially, while tellers appointed by both Houses were employed purely for purposes of enumeration. From I82I to I86I it was generally held that a casus omissus existed in the Constitution, and that no particular person was empowered formally to "count" the electoral votes. In I86I Congress declared that it had the right to "count" the electoral votes as an affirmative act, and that Congress also had a right to determine their legality. ${ }^{64}$ In 1865 the theory of Congressional control found expression in the adoption of the $22 \mathrm{~d}$ Joint Rule.

${ }^{\infty}$ The Presidential Connts (1877) 257.

on Ibid. 258.

McKnight, op. cit. supra note 33 , p. 3 Io.

${ }^{\infty}$ McKnight, ibid. I5.

ougherty, op. cit. supra note 25. ch. 3; Lalor, op. cit. supra note 24, pp. 64, 65 . 
In 1869 and in 1873 the electoral counts proceeded under the operation of the 22 doint Rule, and in I873 the votes of Arkansas, Louisiana, and Georgia were excluded by the two Houses. But on January 20 , I876, the House of Representatives having become Democratic, the Senate repealed the 22d Joint Rule. Congress might have reverted to the old theory of the electoral count and passed a general law providing for a full authentication of the electoral votes of the states with the control of the count vested in the President of the Senate. Instead, however, Congress passed an act placing the control of the electoral count in the hands of an Electoral Commission composed of five Senators, five Representatives, and five Justices of the United States Supreme Court. ${ }^{65}$ The constitutionality of such an act was doubtful. In discussing this point a prominent publicist observes: "Of the utter illegality of the electoral commission, of the lack of power in Congress to take the appointment of the electors away from the states, there can be no doubt." $"$ 6

As a result of the findings of the Electoral Commission, Rutherford Hayes and William A. Wheeler, the candidates of the Republican Party, were formally declared President and Vice-President of the United States. ${ }^{87}$

The last important legislation passed by Congress regulating the electoral count is the act of February 3, $1887 .^{68}$ The first section of this statute substitutes the second Monday in January for the first Wednesday in December as the day on which the electors of each state should meet and give their votes. Section two provides that every judicial decision or determination of a contest relative to the appointment of an elector must be settled "at least" six days before the time fixed for the meeting of the electors."

This congressional requirement that the State decision must be reached at least six days before the second Monday in January is open to serious constitutional objections. Representative Dibble, in discussing section two, remarked as follows: "Up to the day of election, the day when the electors are to cast their votes, the State power as to appointment cannot be interfered with in any manner, shape, or form by the Congress of the United States, or by any other power. Up to that time the State stands fortified by the privilege granted in the Constitution. The fact that the day is to be designated by Congress and is to be the same throughout the United States of course limits the time when the appointing power can be exercised."

Under the terms of section three the executive of each state is required

\footnotetext{
${ }^{65}$ Haworth, The Disputed Election of 1876 (I906) chs. Io, II; Dunning, Reconstruction, Political and Economic (I907) ch. $2 \mathrm{I}$.

${ }^{e}$ Lalor, op. cit. supra note 24, p. 65.

"Haworth, op. cit. supra note 65, ch. II; Stanwood, op. cit. supra note $26, \mathrm{pp}$. 356-393.

Act of Feb. 3, 1887 (24 Stat. at L. 373).

(1887) 18 Cong. Rec. 46.
} 
to communicate to the Secretary of State of the United States a certificate indicating the names of the electors and the votes given or cast for each candidate for that office. But no provision is made in case the executive of a state refuses compliance with the statute.

It was section four of the act that evoked the most animated debate. It provided for the joint meeting in the House of Representatives, the appointment of tellers, and the announcement of the electoral count. After such formalities have been completed, "the President of the Senate shall call for objections, if any. Every objection shall be made in writing, and shall state clearly and concisely, and without argument, the ground thereof, and shall be signed by at least one Senator and one member of the House of Representatives before the same shall be received. When all objections so made to any vote or paper from a State shall have been received and read, the Senate shall thereupon withdraw, and such objections shall be submitted to the Senate for its decision; and the Speaker of the House of Representatives shall, in like manner, submit such objections to the House of Representatives for its decision; and no electoral vote or votes from any State which shall have been regularly given by electors whose appointment has been lawfully certified to according to Section 3 of this act, from which but one return has been received, shall be rejected, but the two Houses may reject the vote or votes when they agree that such vote or votes have not been so regularly given by electors whose appointment has been so certified."70

The principal objection to the power conferred upon Congress by this clause was cogently stated by Senator Sherman in January, I886. "That," he argued, "is a dangerous power. It allows the two Houses of Congress, which are not armed with any constitutional power whatever over the electoral system, to reject the vote of every elector of every State, with or without cause, provided they are in harmony in that matter."'11 According to Mr. J. H. Dougherty, who in his treatise on the Electoral System of the United States discusses in detail this last important act of Congress regulating the electoral count, the language of Senator Sherman is none too strong. "If a Congress, protected by an adequate vote in each chamber, wished to destroy the Government," remarks Mr. Dougherty, "this provision would enable it to do so. It permits a majority, upon technical grounds, to defeat the popular will, to nullify constitutional government, and prevent the inauguration of a new President; and the danger grows out of the fact that Congress has invaded a province or department of the Government which the framers of the Constitution planned to keep absolutely aloof from and independent of the legislative branches." ${ }^{32}$

${ }^{70}$ Act of Feb. 3, I887 (24 Stat. at L. 373).

71 (1886) I7 Cong. Rec. 8I6.

Dougherty, op. cit. supra note 25, p. 235. 